\title{
Peradaban Melayu Kuno: Sejarah, Budaya, dan Ekonomi Serdang dalam Novel Penari Dari Serdang Karya Yudhistira ANM Massardi
}

\author{
Muhammad Zulaemy ${ }^{a, 1}{ }^{,}$,Eggy Fajar Andalas ${ }^{b, 2}$ \\ ab Universitas Muhammadiyah Malang, Jalan Raya Tlogomas 246, Malang, Indonesia, 65144 \\ ${ }^{1}$ muhammadzulaemy@gmail.com; 2eggy@umm.ac.id \\ * Corresponding Author
}

\begin{tabular}{l}
\hline INFO ARTIKEL \\
\hline Sejarah Artikel: \\
Diterima: 3 April 2020 \\
Direvisi: 6 April 2020 \\
Disetujui: 11 April 2020 \\
Tersedia Daring: 12 April \\
2020 \\
\hline
\end{tabular}

\section{ABSTRAK}

Dalam sejarah bangsa Indonesia peradaban Melayu menempati posisi yang penting. Berbagai bentuk kebudayaan bangsa saat ini tidak bisa dilepaskan begitu saja dari sejarah peradaban Melayu. Meskipun begitu, sangat sedikit hasil penelitian yang dilakukan terhadap kebudayaan Melayu di Indonesia. Berbagai hasil penelitian yang ada lebih berpusat pada kebudayaan Jawa. Melalui novel Penari Dari Serdang, Yudhistira ANM Massardi menggambarkan

Kata Kunci:

New historicism

Penari dari serdang

Melayu kuno peradaban yang menjadi cikal bakal terbentuknya sebuah daerah yang bernama Serdang yang pada kenyataannya memiliki struktur sejarah yang panjang. Artikel ini bertujuan menggabarkan sejarah peradaban Melayu kuno yang tergambarkan dalam novel Penari Dari Serdang karya Yudhistira ANM Peradaban Massardi. Dengan menggunakan perspektif new historicism yang menekankan pada hubungan dialektis antara aspek sejarah sebagai latar belakang terciptanya karya sastra dan teks sastra, artikel ini berpendapat bahwa karya ini menyoriti dimensi sejarah, budaya, dan ekonomi di Serdang pada masa kejayaan Melayu kuno. Berbagai gambaran yang ada di dalam novel ini memperlihatkan kesejajaran struktur dengan realitas pada dokumen-dokumen sejarah yang ada. Di sisi lain, novel ini juga memberikan kritik terhadap sikap pemerintah saat ini yang abai terhadap sejarah masa lalu yang kaya, utamanya di wilayah Serdang.

\begin{tabular}{ll}
\hline ABSTRACT \\
\hline $\begin{array}{l}\text { Kew Historicism } \\
\text { Penari dari Serdang }\end{array}$ & Throughout Indonesian history, Malay civilization occupies an important \\
Ancient malay & position. Various forms of national culture today cannot be separated from the \\
Civilization & history of Malay civilization. Even so, very few results of research conducted \\
& on Malay culture in Indonesia. Various research results that are more centered \\
& on Javanese culture. Through the novel Penari Dari Serdang, Yudhistira ANM \\
& Massardi described the civilization that became the forerunner to the \\
& formation of an area called Serdang which in reality has a long historical \\
& structure. This article aims to describe the history of ancient Malay civilization \\
& as illustrated in the novel Penari Dari Serdang by Yudhistira ANM Massardi. \\
& Using a new historicism perspective that emphasizes the dialectical \\
& relationship between historical aspects as a backdrop for the creation of \\
& literary works and literary texts, this article argues that this work highlights \\
the historical, cultural and economic dimensions in Serdang during the heyday \\
of ancient Malay. The various images in this novel show the alignment of \\
structure with reality in existing historical documents. On the other hand, this \\
novel also provides criticism of the current government's attitude which is \\
ignorant of its rich past history, especially in the Serdang region.
\end{tabular}

(C) 2020, Zulaemy \& Andalas This is an open access article under CC-BY license (c) (i) (2) 
How to Cite: Zulaemy, M., \& Andalas, E. F. (2020). Peradaban Melayu Kuno: Sejarah, Budaya, Ekonomi Serdang dalam Novel Penari Dari Serdang Karya Yudhistira ANM Massardi. JURNAL SATWIKA, 4 (1), 71-83. doi: https://doi.org/10.22219\%20/SATWIKA.Vol4.No1.71-83

\section{Pendahuluan}

Dalam sejarah bangsa Indonesia, peradaban Melayu menempati posisi yang penting. Selain bahasa Indonesia modern yang berasal dari bahasa Melayu Riau, berbagai bentuk kebudayaan bangsa saat ini tidak bisa dilepaskan begitu saja dari sejarah peradaban Melayu (Abdullah, 2017; Azhari, 2013; Hashim, 1988; Putra, 2016). Meskipun begitu, sangat sedikit hasil penelitian yang dilakukan terhadap kebudayaan Melayu di Indonesia. Berbagai hasil penelitian yang ada lebih berpusat pada kebudayaan Jawa atau Jawa-sentris (Mohammad, 2017).

Sejatinya, sejak masuknya Islam, kurun abad ke-14-15 Masehi, ke wilayah Nusantara bersamaan dengan itu juga mulai dikenal sistem penulisan aksara, yaitu tulisan Jawi (Salleh, 1997:227). Pada mulanya, tradisi penulisan berkembang di lingkup istana dan menghasilkan catatan genealogi, biografi, dan catatan harian istana yang pada akhirnya kemudian menjadi embrio lahirnya sastra bercorak sejarah di kawasan Melayu (Zakaria, Ali, Wahid, \& Omar, 2018:194).

Meskipun telah banyak karya sastra bergenre sejarah, keberadaan antara sejarah sebagai dokumen resmi dan sastra sebagai karya kreatif dan imajinatif sering diperdebatkan. Terdapat pemisahan yang begitu tegas antara hal yang disebut sebagai sejarah dan hal yang bukan.

Berkaitan dengan hal tersebut, Teeuw (1974:3), menyatakan bahwa hendaknya sastra dipahami dan dibaca sebagai sebuah karya bercorak imajinatif dan kreatif. Meskipun begitu, hal yang patut untuk diperhatikan juga adalah berbagai gambaran yang ada di dalam karya sastra merupakan realitas kehidupan sehari-hari (Andalas, 2016a, 2017b, 2018c). Berbagai bahan baku karya sastra berasal dari kehidupan manusia. Karenanya, sebuah karya sastra hendaknya dipahami bukanlah sebagai sebuah karya sastra yang seluruhnya menggambarkan realitas, begitupun juga bahwa karya sastra tidaklah seluruhnya merupakan imajinasi semata (Andalas, 2018a; Farida \& Andalas, 2019a, 2019b; Sugiarti \& Andalas, 2018). Diperlukan sebuah interpretasi yang dapat menjembatani antara struktur fiksional dan struktur realitas dalam sebuah karya sastra.

Wellek and Waren (2014:38), menyatakan bahwa sebuah karya sastra dapat dilihat sebagai deretan karya yang tersusun secara kronologi dan menjadi bagian dari proses sejarah. Dengan kata lain, karya sastra menjadi dokumen sekaligus representasi dari berbagai realitas sejarah yang terjadi dalam kehidupan manusia (Andalas, 2017a, 2018b; Iman \& Andalas, 2019; Sulistyorini \& Andalas, 2017). Berdasarkan hal tersebut perlu adanya sebuah kerangka pemikiran yang memperhatikan antara kesejajaran terhadap dimensi fiksional dan realitas dalam sebuah karya sastra. Novel Penari Dari Serdang merupakan salah satu karya sastra bergenre sejarah yang perlu untuk diperhatikan.

Novel Penari Dari Serdang (2019) karya Yudhistira ANM Massardi merupakan salah satu novel yang berkisah tentang sejarah Melayu kuno di wilayah Serdang, Sumatera Utara. Melalui pengisahan cinta antara Bagus dan Chaya penulis menggambarkan kejayaan Melayu kuno. Bagus digambarkan sebagai seorang sastrawan yang berasal dari ibu kota dan Chaya sebagai seorang guru tari. Keduanya dipertemukan dalam sebuah acara lomba sastra dan kebudayaan di kota Serdang. Melalui pengisahan kedua tokoh tersebut, pengarang menceritakan mengenai sejarah kebudayaan Melayu yang ada di Serdang.

Banyak cerita yang membuat Bagus tertarik terhadap kebudayan Melayu kuno yang berada di Serdang melalui penuturan Chaya. Hingga akhirnya, Bagus menyadari sebuah fakta bahwa berbagai kekayaan peradaban Melayu kuno yang menjadi cikal 
bakal wilayah Serdang telah rusak, terbengkalai, bahkan lenyap. Melalui Tengku Natshya, sahabat karib Chaya sekaligus cucu dari Sultan Sulaiman, diungkapkan jika pemerintah hanya memberikan sedikit perhatian terhadap hal tersebut.

Melalui novel Penari Dari Serdang, Yudhistira ANM Massardi menggambarkan peradaban yang menjadi cikal bakal terbentuknya sebuah daerah yang bernama Serdang. Wilayah ini memiliki struktur sejarah yang panjang. Sayangnya, kekayaan tersebut tidak diperhatikan oleh pemerintah setempat. Berbagai gambaran mengenai peradaban Melayu kuno dalam novel ini penting untuk diperhatikan. Berbagai kekayaan budaya yang ada di dalamnya menjadi media bagi pembelajaran dan sarana pemertahanan tradisi bagi generasi saat ini (Andalas, 2016b:122-123; Ariani \& Andalas, 2018; Qur'ani \& Andalas, 2019:238). Berdasarkan catatan Azhari (2013:iii-iv), peradaban Melayu kuno di Indonesia telah ada sejak abad ke-7 dan terdapat sekitar 50 kerajaan di Nusantara yang berakar pada kebudayaan Melayu. Berbagai peninggalan kejayaan peradaban Melayu kuno salah satunya banyak terdapat di kota Serdang, Sumatera Utara.

Berdasarkan studi literatur yang dilakukan, penelitian terhadap eksplorasi kekayaan peradaban Melayu kuno yang terdapat dalam novel Penari Dari Serdang karya Massardi (2019) belum pernah dilakukan. Padahal, novel ini kaya akan nilainilai sejarah peradaban Melayu kuno yang dapat meningkatkan pengetahuan generasi saat ini. Selain itu, Purnamasari (2019) dalam studinya mengenai kajian new historicism terhadap novel Arok Dedes menemukan kesejajaran realitas antara hal yang tergambarkan dalam dokumen sejarah dengan penggambaran dalam novel yang ditelitinya. Hal ini memperlihatkan bahwa realitas fiksional dalam karya sastra tidak dapat dipahami sebagai hasil fiksi seluruhnya. Studi yang dilakukan oleh Ardhianti (2016) dan Sahliyah (2017) juga mendukung hal yang disampaikan oleh Purnamasari (2019). Keduanya menggambarkan mengenai realitas politik, budaya, sosial, dan ekonomi dalam novel yang bertalian erat dengan realitas sejarah.

Berdasarkan hal tersebut, sebagai gambaran dari kejayaan peradaban Melayu kuno, novel Penari Dari Serdang penting untuk diteliti. Sebagai karya sastra bergenre sejarah, novel ini kaya akan gambaran mengenai sejarah peradaban Melayu kuno yang hidup di wilayah Sumatera Utara. Artikel ini bertujuan menggambarkan sejarah peradaban Melayu kuno yang ada dalam novel Penari Dari Serdang karya Massardi (2019).

Penelitian ini menggunakan perspektif new histroricism. New historicism merupakan kritik sastra yang melihat hubungan antara realitas dalam karya sastra dalam kaitannya dengan realitas sosial, ekonomi, dan budaya dalam kehidupan nyata (Brannigan, 1999:421). Dengan kata lain, penelitian ini berasumsi bahwa novel Penari Dari Serdang merupakan cermin dari realitas yang terjadi di masa lalu dan dokumen yang merekam berbagai peristiwa tersebut dalam bentuk karya imajiner.

Pendekatan ini, salah satunya, diperkenalkan oleh Stephen Greenbalt. Ia menyatakan bahwa perspektif ini memusatkan perhatiannya pada latar belakang ekonomi dan sosial yang melatarbelakangi sebuah karya sastra karena pembahasan terhadap hal tersebut tidak harus selalu berupa teks yang nyata (Greenblatt, 1982; Greenblatt \& Gallagher, 2005). Hal ini karena pada realitasnya, karya sastra sering menjadi wacana tandingan terhadap versi sejarah yang diciptakan atau ditulis oleh rezim yang berkuasa pada saat sejarah tersebut ditulis. Melalui asumsi ini, perspektif new historicism memerlukan kerangka kerja intertekstualitas dengan membandingkan antara karya sastra dengan teks-teks non sastra (Barry, 2010:203).

Perspektif new historicism merupakan pendekatan yang heterogen. Meskipun begitu, terdapat beberapa kesamaan asumsi dasar, yaitu 1) setiap tindakan berelevansi dengan praksis budaya, 2) penyandingan antara teks sastra dan non-sastra tidak 
dilakukan secara terpisah, dan 3) tidak adanya pengakuan "tegas" terhadap unsur fiksional dan realitas terhadap teks dalam merumuskan kebenaran mutlak sebuah teks (Mumtaz, 2014:14; Taum, 2013:2). Sastra tidak bisa dipandang sebagai hal yang begitu saja terlepas dari sejarah dan karya imajinatif semata (Foucault, 2012:85).

Greenblatt and Gallagher (2005:6-7), mengemukakan bahwa realitas yang terdapat dalam dunia karya sastra bukanlah sebuah alternatif melainkan sebuah cara untuk mengintensifkan sebuah dunia yang sekarang kita huni. Greenblatt juga mengatakan jika new historicism melibatkan sesuatu yang dikenal dengan "thick description" atau deskripsi yang mendalam. Istilah yang diperkenalkan oleh Antropolog Amerika, Clifford Geertz. Dalam pengertian ini, peneliti tidak hanya mencari realitas yang ada di dalam sejarah melainkan juga mencari makna yang mendasar dari proses sejarah yang melatarbelakangi kejadian tersebut.

\section{Metode}

Penelitian ini berjenis kualitatif. Pendekatan yang digunakan adalah new historicism. Dalam pendekatan ini interpretasi dilakukan dengan menekankan pada aspek sejarah sebagai latar belakang terciptanya karya sastra dan relevansinya terhadap teks sastra. Hubungan ini dipandang sebagai hubungan dialektis yang tidak mengedepankan salah satu teks lebih penting dibandingkan teks yang lainnya.

Sumber data yang digunakan adalah novel Penari Dari Serdang (2019) karya Yudhistira ANM Massardi. Data dalam penelitian ini berupa kutipan-kutipan, katakata, atau kalimat yang menunjukkan tentang aspek sejarah, aspek ekonomi, serta aspek sosial dalam peradaban sejarah Melayu kuno di kota Serdang yang terdapat dalam novel Penari dari Serdang karya Yudhistira ANM Massardi.

Teknik pengumpulan data yang dilakukan adalah teknik simak-catat. Dalam pengumpulan data dilakukan pencarian dan pembacaan secara dekat terhadap sumber data yang digunakan kemudian dilakukan pencatatan terhadap data-data yang relevan dengan tujuan penelitian (Sugiarti, Andalas, \& Setiawan, 2020:82-85). Setelah data terkumpul dilakukan analisis. Teknik analisis dilakukan dengan penyajian data, interpretasi berdasarkan teori yang digunakan, dan penarikan kesimpulan. Adapun tahapan tersebut, yaitu 1) pengumpulan data dan klasifikasi data dalam novel Penari Dari Serdang, 2) reduksi data, berupa hasil yang telah diklasifikasi selanjutnya dikelompokkan sesuai dengan kebutuhan penelitian, 3) menyajikan data dalam novel Penari dari Serdang karya Yudhistira ANM Massardi dengan cara mendeskripsikannya sesuai dengan teori new historicism, yakni sejarah, budaya dan ekonomi, berupa kata atau kalimat, paragraph, serta tuturan tokoh sesuai dengan rumusan masalah, 4) menyimpulkan hasil analisis data dalam novel Penari dari Serdang karya Yudhistira ANM Massardi sesuai dengan kajian penelitian.

\section{Hasil dan Pembahasan}

Novel Penari dari Serdang karya Yudhistira ANM Massardi berkisah tentang sejarah Melayu yang terdapat di Sumatera Utara, tepatnya daerah Serdang. Novel ini dibagi menjadi 89 bagian, dengan beberapa bagian terfokus pada sejarah Melayu di semenanjung Nusantara tanpa adanya sisipan kisah romantis antara Bagus dan Chaya. Kisah-kisah yang dipaparkan dalam novel ini menjadi acuan tentang bagaimana perkembangan sejarah Melayu di daerah Serdang. Berikut adalah hasil paparan dari berbagai aspek yang melatarbelakangi perkembangan sejarah Melayu di kota Serdang dalam novel Penari Dari Serdang.

\subsection{Sejarah Melayu Serdang}

Sejarah seperti yang dikatakan oleh Budianta (2006:4), bahwa "sejarah terdapat di dalam sebuah karya sastra bukan hanya menjadi latar belakang sebuah cerita, tetapi juga ada susunan serta rentetan cerita nyata di dalam sejarah yang kemudian dituangkan ke dalam sebuah karya sastra". Dengan kata 
lain, keterkaitan antara sastra dengan sejarah terletak pada hubungan intertekstualitasnya.

Seperti yang telah disebutkan sebelumnya bahwa sejarah peradaban Melayu kuno yang diketahui telah masuk ke Nusantara mulai dari abad ke 7 dan lebih dari puluhan kerajaan yang berdiri di semenanjung Nusantara berakar pada kebudayaan Melayu. Menurut kutipan dari novel Penari dari Serdang "kedatangan Melayu menghubungkan poros JambiPalembang-Padang-Medan-Aceh-Riau-Jawa Tengah-Jawa Barat-Malaysia-Brunei Darussalam. Beberapa kutipan dalam novel Penari dari Serdang menjelaskan secara rinci tentang perkembangan sejarah Melayu terutama di pulau Sumatera. berdasarkan hasil wawancara dengan antropolog Dr. Kusnin Asa dalam kutipan berikut.

"Sejak pertengahan Abad IV Masehi, Sumatera merupakan jantung peradaban bangsa-bangsa dari wilayah barat dan utara Asia Tenggara. Orang- orang Arya dari India telah melakukan asimilasi dengan bangsa-bangsa di kawasan Mikronesia dan menjadi bangsa polinesia.” (Massardi, 2019:153).

Sesuai dengan penuturan dari Dr. Kusnin Asa mengenai bagaimana perkembangan dari sejarah melayu di pulau Sumatera dapat dilihat bahwa pertengahan Abad IV adalah awal mula Sumatera menjadi gerbang masuknya berbagai bangsa, termasuk juga bangsa Melayu. Hal ini karena letaknya di bagian pesisir Barat Nusantara sehingga memudahkan para imigran untuk memasuki kawasan Nusantara sekaligus menjadikan pulau Sumatera menjadi awal peradaban pelbagai bangsa. Abad V hingga Abad VI menjadi kejayaan atas kerajaankerajaan besar di Nusantara, seperti Kantoli (Kendali) yang menjadi kerajaan pertama dan berakar budaya Melayu (Massardi, 2019:154). Sebagaimana fungsi dari sejarah, yaitu sebagai tafsiran dan penjelasan yang memberikan pengertian pemahaman tentang apa yang telah terjadi pada masa lampau (Kartodirjo, 1992:12), maka apa yang diungkapkan oleh Dr. Kusnin Asa telah menjelaskan sebuah fakta mengenai suatu deretan abad mengenai awal mula sejarah Melayu muncul di Nusantara hingga membangun kerajaan-kerajaan yang sebagian besar berkembang dengan cepat dan mencapai kejayaan masing- masing. Kerajaan-kerajaan terseebut menguasai seluruh semenajung Nusantara, mulai dari gugusan pulau-pulau di Indonesia, Malaysia, hingga Singapura. Fakta yang didapatkan tidak berakhir hanya tentang perkembangan Melayu pada abad-abad tersebut, melainkan juga fakta mengenai pulau Sumatera sebagai pintu strategis gerbang Barat Nusantara yang menjadi pusat peradaban Melayu Kuno bangsa-bangsa daerah Barat dan Utara Asia Tenggara.

Kesultanan Serdang yang telah kita ketahui berhasil mencapai puncak kejayaannya pada saat pemerintahan Sultan Sulaiman dan zaman keemasan pada saat pemerintahan Sultan Thaf Sinar Baharshah. Pada masa ini Kesultanan Serdang mencapai awal kemakmuran atas kerjasama perdagangan yang diterapkan dalam kesultanan. Meskipun begitu, dalam kondisi ini kesultanan mengalami pergejolakanpergejolakan sehingga terjadi peperangan. Dalam novel, salah satu buku yang dibaca oleh Bagus tentang Sultan Sulaiman ia dapatkan setelah berkunjung ke perpustakaan bekas kediaman Sultan Muda Perkasa.

"Peristiwa yang digerakkan dengan semangat menumpas feodalisme itu, menelan ratusan korban keluarga para bangsa Melayu, khususnya dari Kerajaan Langkat. Mereka dirampok, dibantai, dan diperkosa, Istana Kesultanan Langkat dan Kesultanan Serdang habis dibakar." (Massardi, 2019:91)

Kutipan tersebut menjelaskan tentang sebuah kisah dikala Sultan Sulaiman muda ingin merebut kembali tiga daerah yang sudah dirampas oleh Belanda. Perlawanan itu bertujuan untuk mengembalikan lahan yang digunakan oleh masyarakat Serdang 
untuk perkebunan karet dan tembakau pada 17 Mei 1872. Sultan Sulaiman yang semenjak dilantik, berumur 15 tahun, hingga beberapa tahun setelahnya ketika menjabat sebagai Sultan, namanya sudah masuk dalam daftar Belanda sebagai orang yang diwaspadai. Ia diwaspadai karena gerakangerakan yang dilakukannya menentang kebijakan Belanda. Namun, karena hal itu, Kesultanan Serdang hampir runtuh ketika terjadi pergejolakan besar dalam perebutan wilayah. Dalam percakapan berikutnya, Chaya pun mengatakan jika Indonesia sebenarnya mempunyai hutang yang besar terhadap bangsa Melayu karena bagaimana pun Bahasa Melayu menjadi cikal bakal dari Bahasa Indonesia.

Data-data yang ditemukan dalam novel menjadi pelengkap dari buku sejarah resmi yang ditulis oleh Azhari (2013) berjudul Kesultanan Serdang. Berdasarkan telaah terhadap keduanya diperoleh fakta bahwa kedua teks ini saling melengkapi satu sama lain. Dalam novel Penari dari Serdang hanya diceritakan persoalan perkembangan berbagai kerajaan yang berdiri di Sumatera secara ringkas dan buku Kesultanan Serdang menjelaskannya secara lebih rinci. Dalam buku tersebut penulis menuliskan berikut.

"Pada abad ke-18 berdiri pula Kesultanan Sedang yang wilayah kekuasaannya berdampingan dengan Kesultanan Deli (Abad-17). Kedua kesultanan ini juga masih memiliki hubungan kekerabatan, karena menurut Sinar, sultan pertama di wilayah Serdang adalah salah seorang cucu dari Seri Paduka Gocah Pahlawan yang bernama Tuanku Umar Johan Pahlawan (pendiri kesultanan Deli)." (Azhari, 2013:1)

Seperti yang telah dibahas dalam kutipan tersebut bahwa Kesultanan Serdang akhirnya berdiri 13 abad setelah beberapa Kerajaan yang juga berbasis Melayu akhirnya mendapatkan kejayaan. Perjalanan dari sejarah Kesultanan Serdang itu sendiri masih dipengaruhi oleh Kesultanan sebelumnya, yaitu Kesultanan Deli karena Kesultanan
Serdang didirikan oleh cucu dari pendiri Kesultanan Deli. Kesultanan Serdang juga memiliki tokoh penting sekaligus menjadi pusat atas terbentuknya Kesultanan Serdang, yaitu seorang Panglima Armada Kesultanan Aceh Darussalam, Tuanku Sri Paduka Gocah Pahlawan (Sinar, 1986:19). Namun seiring dengan perjalanan waktu, realitas sejarah yang telah terjalin tersebut menyebabkan kemudahan tersendiri bagi Kesultanan Serdang yang memiliki kekerabatan dengan Kesultanan sebelumnya. Kesultanan Serdang pada akhirnya mencapai puncak kejayaannya pada saat diperintah oleh seorang sultan bernama Sultan Sulaiman Shariful Alamsyah yang diangkat menjadi seorang sultan dikala umurnya masih 15 tahun.Akibat peristiwa ini Belanda yang berkuasa dan menetap di sekitar kawasan Serdang merasa tidak senang sehingga pemerintah Belanda mencatat namanya karena tuntutan daerah kekuasaan yang mereka rebut dari Kesultanan Serdang (Azhari, 2013:4).

\subsection{Budaya Melayu Serdang}

Budaya yang ada di dalam novel Penari dari Serdang lebih mengarah kepada bagaimana hasil budaya orang Melayu kuno dalam membangun sebuah tempat yang diberi nama Serdang. Latar belakang budaya merupakan aspek utama dalam new historicism seperti yang dikatakan oleh Budianta (2006:8) bahwa "unsur budaya yang terdapat dalam karya sastra yang secara tidak langsung budaya telah menjadi pemanis dalam karya sastra...bukan sekadar pelengkap, namun budaya akan membuat karya sastra akan lebih menarik untuk dinikmati". Salah satu data budaya yang ditemukan dalam novel Penari dari Serdang adalah sebagaimana kutipan berikut.

"Itu rumah kediaman Sultan Serdang
terakhir, mendiang Sultan Muda Perkasa.
Beliau juga pakar sejarah dan kebudayaan
Melayu. Buku-buku karnyanya menjadi
rujukan penting bagi studi kebudayaan
Melayu. Semua buku koleksinya
disumbangkan kepada masyarakat


melalui perpustakaan itu." (Massardi, 2019:11)

Kutipan tersebut diambil dalam percakapan antara Chaya dan Bagus ketika mengelilingi kota Serdang. Kutipan ini menunjukkan sebuah fakta jika pada dahulunya kediaman para Sultan sudah dijadikan tempat untuk proses pembelajaran maupun pengajaran. Beberapa hal juga disinggung dalam percakapan itu adalah para sultan pun tetap turut andil dalam pelestarian budaya maupun sejarah Melayu sehingga mereka juga tetap ikut menulis tentang budaya maupun sejarah Melayu yang berada maupun berkembang di Serdang. Dukungan yang diberikan dengan menyediakan tempat penyimpanan buku maupun barang-barang yang menjadi peninggalan dari sejarah Melayu sebelumnya. Bahkan, Sultan Muda Perkasa menjadikan kediamannya sebagai perpustakaan. Kutipan tersebut sebagai bukti bahwa sultan memiliki peran penting dalam pemerintahan kesultanan hingga banyak dari para sultan yang menjadi sastrawan, ulama, penulis produktif, hingga pemikir agama yang cerdas. Sultan Sulaiman dan beberapa sultan lainnya merelakan kediaman serta beberapa lahan kesultanan sebagai tempat pengajaran dan pembelajaran maupun tempat beribadah untuk orang-orang umum. Mereka juga mendirikan perpustakaan untuk menyimpan tulisan dari para sultan terdahulu hingga sebagai tempat penyimpanan barangbarang berharga milik kesultanan.

Selo Soemarjdan dan Soeleman Soemardi merumuskan kebudayaan sebagai semua hasil karya, rasa, dan cipta masyarakat. Melalui kebudayaan yang merupakan karya dari masyarakat yang bersifat kebendaan maupun yang kebudayaan secara ragawi yang yang akan diperlukan oleh masyarakat sekitar untuk dipergunakan dalam mengelola alam sekitarnya agar hasil alaam yang diperoleh dapat dimanfaatkan untuk kebutuhan masyarakat sekitar (Ranjabar, 2006:21).

Kebudayaan lainnya yang ditampilkan dalam novel Penari dari Serdang adalah tarian. Hal itu terdapat dalam kutipan berikut. “...aneka tari Melayu tradisional yang berpedoman pada koreografi ciptaan Guru Sauti, maestro tari Melayu kelahiran Perbaungan. Jenis-jenis tarinya antara lain Tari Lenggang Patah Sembilan, Tari Lenggok Mak Inang, Tari Dua Lagu, Tari Campak Bunga, Tari Melenggok, Tari Pelipur Lara, dan Tari Serampang Duabelas." (Massardi, 2019:82)

Sebagaimana kebudayaan adalah hasil karya dari masyarakat yang bersifat ragawi maupun kebendaan, maka tarian adalah salah satu kebudayaan secara ragawi. Tarian juga bisa dikatakan sebagai warisan identitas suatu tempat. Tarian biasa dipersembahkan untuk acara keadatan maupun hal-hal lainnya. Oleh karenanya, tarian harus terus dilestarikan dan juga diajarkan kepada generasi penerus. Seperti yang telah disebutkan dari kutipan di atas mengenai beberapa bentuk tarian Melayu yang ada dalam sejarah Serdang. Cerita Chaya yang menjadi pengajar tari menjadi landasan bahwa sampai saat ini tarian-tarian itu masih terus berusaha untuk dilestarikan. Wujud tarian Melayu Tradisional yang penting untuk dilestarikan, melalui penjelasan Chaya mengenai tarian khas Melayu dalam novel, beberapa di antara tujuh tarian, yaitu Tari Serampang Duabelas. Tarian ini penting untuk dijarkan kepada anak-anak.

Tarian Serampang Duabelas dilakukan secara berpasang-pasangan karena tarian ini mengisahkan tentang kisah percintaan dua sejoli pada pandangan pertama mereka dan pada akhirnya menikah dan direstui oleh seluruh keluarga. Tarian Serampang Duabelas diiringi oleh lagu Pulo Sari, tarian ini memiliki gerakan yang bertempo cepat karena dahulu mendapat pengaruh dari Portugis dan Sepanyol. Sesuai dengan namanya, tarian Serampang Duabelas terbagi atas duabelas ragam gerakan yang megekpresikan proses percintaan sejak awal bertemu hingga mengungkapkan perasaan mereka satu sama lain. Ada hal lain dalam gerakan tarian itu selain mengungkap 
perasaan masing-masing, yaitu cermin atas perilaku setia terhadap adat. Fakta dari tarian Serampang Duabelas adalah tarian ini terus diadakan perbaikan untuk penyempurnaan mulai tahun pertama kali diciptakan 1940 hingga terakhir kali diperbaiki pada tahun 1960 (Massardi, 2019:82).

Kebudayan Melayu kuno lain juga ditemukan dalam buku Kesultanan Serdang sebagai karya nonsastra yang disandingkan atas novel Penari dari Serdang. Sebagai gerbang Nusantara, terutama Pulau Sumatera, fakta yang di kemukakan oleh J.C Van Leur adalah Barat laut Sumatera, yaitu di Barus, sudah ada koloni-koloni Arab yang singgah untuk berdagang dan juga berdakwah (Azhari, 2013:19-20). Hasil dari kebudayaan yang berkembang dan didominasi oleh doktrin para pedagang dari Arab menyebabkan sejarah Melayu lekat hubugannya dengan ke-Islaman. Budaya Islam yang berkembang dalam sejarah melayu disebutkan dalam kutipan berikut.

“...,para ulama ini juga mendirikan pesantren-pesantren sebagai sarana pendidikan Islam. Para wali ini dekat dengan kalangan istana. Merekalah orang yang memberikan pengesahan atas sah tidaknya seseorang naik tahta. Mereka juga adalah penasihat sultan sehingga diberi gelar sunan atau susuhunan (yang dijunjung tinggi).” (Azhari, 2013:21)

Islam mulai berkembang dengan pesat di Nusantara berkat para mubaligh (orang yang berdakwah) yang dengan giat menyebarkan agama Islam. Mereka tidak hanya menyebarkan agama Islam melalui perdagangan, namun mereka juga menikahi penduduk setempat sehingga penduduk setempat yang telah memeluk Islam juga ikut andil dalam penyebaran agama Islam pada sanak famili maupun kenalan yang ada di lingkungannya. Kebudayaan Islam dan sejarah Melayu memiliki keterkaitan erat yang bisa dilihat hingga saat ini. Adapun fakta yang merujuk tentang perkembangan kebudayaan Islam di Nusantara berdampingan dengan tumbuhnya kerajaan- kerajaan di Pulau Sumatera dan juga di Nusantara adalah perkataan dari Marco Polo, seorang penjelajah yang pada abad ke-13 tepatnya tahun 1292. Marco Polo singgah di Perlak dan mengatakan jika ia bertemu dengan orang-orang yang telah menganut agama Islam.

Dalam buku Kesultanan Serdang karya (Azhari, 2013), disebutkan jika pusat dari kebudayaan Islam yang tumbuh di Sumatera lalu menyebar hingga terbentuknya Kesultanan Deli yang merupakan cikal bakal dari Kesultanan Serdang, berpusat di dalam istana kerajaan, di mana Sultan Sulaiman yang menjadi raja disaat Kesultanan Serdang mencapai puncak kejayaan menjadikan istana kerajaan sebagai tempat berlangsungnya kesenian, pembelajaran, pengajaran. Sultan Sulaiman juga mendirikan tempat ibadah umum yang bisa dipergunakan oleh masyarakat pada umumnya.

\subsection{Ekonomi Melayu Serdang}

Aspek ekonomi sama pentingnya dengan aspek budaya karena sama-sama melekat dan berkaitan dengan kehidupan sosial sehari-hari. Budianta (2006:11) menyatakan bahwa aspek ekonomi begitu berpengaruh di dalam berbagai aspek kehidupan. Ekonomi sebagaimana dijelaskan juga oleh Iskandar (2010:1) bahwa ekonomi adalah segala hal yang menyangkut mengenai rumah tanggga, mulai dari perkembangan yang nampak dalam rumah tangga hingga perkehidupan yang terjalin. Kata rumah tangga tidak hanya dibatasi oleh keadaan rumah tangga yang berisikan seorang ayah, ibu, dan anak, melainkan hingga ketahap yang lebih luas, seperti rumah tangga bangsa, negara, maupun dunia.

Serdang, sebuah kota di daerah Sumatera Utara merupakan sebuah wilayah yang telah ada sejak Kesultanan Serdang. Seorang dari keturunan Tionghoa bernama Tjong A Fie, salah satu konglomerat perkebunan di Serdang waktu itu banyak membantu pembangunan infrastruktur di Kota Serdang. Hal ini diperkuat oleh perkataan dari Chaya ketika mengajak Bagus berkeliling kota: 
“... di depan museum rumah Tjong A Fie, konglomerat perkebunan yang banyak membiayai pembangunan infrastruktur di Kota Medan sejak masa kolonial." (Massardi, 2019:21)

Kutipan dari percakapan di atas dibuktikan dengan fakta yang terdapat di dalam novel tersebut sekligus menjadi data tambahan, yaitu

"Perjalanan berlanjut ke Gedung Balai Kota Lama, yang dibangun pada 1908 oleh Hulswit dan Fermont, kemudian direnovasi pada 1923 oleh Eduard Cuypers. Lokasinya merupakan Titik Nol kilometer kota Medan. Gedung itu awalnya dibangun untuk De Javasche Bank (sekarang Bank Indonesia), lalu dibeli oleh pemerintah Kota Medan.

Loncengnya disumbangkan oleh konglomerat perkebunan Tjong A Fie pada 1913. Gedung itu sekarang menjadi bagian dari kompleks hotel dan perkantoran Grand Aston City Hall Medan, dan digunkan sebagai restoran." (Massardi, 2019:18)

Data tersebut dapat dimaknai bahwa pada masa Melayu lampau beberapa orang yang ikut singgah di pulau Sumatera menetap dan tinggal di beberapa bagian pulau Sumatera, terutama beberapa wilayah yang dekat dengan pelabuhan seperti kota Serdang. Beberapa keturunan tak terkecuali mereka yang berdarah Tionghoa pun mendapat peran penting dalam pembangunan budaya di Serdang. Salah satunya adalah konglomerat perkebunan, Tjong A Fie, yang banyak disebutkan membantu banyak pembangunan di kota Serdang. Data di atas pun memberikan informasi mengenai beberapa keturunan yang memilih tinggal di kota Serdang selain dari bangsa Melayu. Selain dari data yang telah disebutkan di atas, beberapa kutipan juga membahas mengenai pembangunan yang dibantu pembiayaannya oleh Tjong A Fie, seperti pembangunan masjid.
“..., pada 1906-1909 Sultan melengkapi kawasan itu dengan membangun Masjid AlMashun, yang lebih dikenal sebagai Masjid Raya Medan. ..., konon konglomerat Tjong A Fie turut membantu pendanaannya." (Massardi, 2019:25)

Kutipan tersebut dimaknai bahwa hingga hal yang mengandung kepercayaan pun tidak mengganggu toleransi antar sesama masyarakat Serdang untuk saling membantu, karena tidak dijelaskan apakah Tjong A Fie menganut kepercayaan apa. Karena bagaimana pun, Melayu dan juga Islam tidak bisa dipisahkan dari peradaban kota Serdang dan hal inillah yang memungkinkan mayoritas masyarakat Serdang pada waktu itu menganut kepercayaan Islam.

Data yang ditemukan di dalam novel Penari dari Serdang ini tidak ditemukan di dalam buku Kesultanan Serdang mengenai seorang keturunan Tionghoa yang bernama Tjong A Fie yang telah banyak berkontribusi terhadap pembangunan bangunan penting pada masa Kesultanan Serdang. Data yang ditemukan tentang perekonomian masyarakat Serdang pada waktu itu lebih menyorot kepada Sultan Sulaiman yang di mana ketika pemerintahan Kesultanan Sulaiman kemakmuran masyarakat Serdang tercapai. Hal ini dibuktikan seperti kutipan berikut.

"Perhatian terhadap kemajuan rakyat dibuktikan dengan melakukan pembangunan di bidang pertanian, ..., Sultan Sulaiman menyediakan lahan persawahan untuk rakyat dan ia juga membangun pengairan untuk menjamin siklus air di persawahan tersebut." (Azhari, 2013:23)

Sultan Sulaiman, seorang raja yang pada masa pemerintahanya Kesultanan Serdang mencapai puncak kejayaan. Namun, bukan hanya jaya pada pemerintahannya saja, melainkan juga dari pasar atau perekonomian masyarakat Serdang. Hal ini ditandai dengan berbagai usaha yang telah dilakukan oleh Sultan Sulaiman, mulai dari membuat irigasi 
untuk pengairan sawah sehingga mempermudah masyarakat dalam pengelolaan sawah-sawah mereka.

Perekonomian kota Serdang juga didukung oleh keadaan wilayah Pulau Sumatera, utamanya Sumatera Utara yang menjadi gerbang masuk para pedagang dan menjadi pusat perdagangan yang sangat ramai di Asia Tenggara (Azhari, 2013:32). Karenanya, raja memiliki hubungan diplomatik dengan dinasti di luar Nusantara. Beberapa faktor juga merujuk kepada kekuatan politik maupun kekuatan panglima tempur yang telah berhasil merebut dan menaklukkan beberapa negeri yang berada di Pantai Barat dan Timur Sumatera.

\section{Kesimpulan}

Novel Penari Dari Serdang karya Yudhistira ANM Massardi merupakan dokumen sejarah peradaban Melayu kuno. Karya ini menyoriti dimensi sejarah, budaya, dan ekonomi di Serdang pada masa kejayaan Melayu kuno. Melalui pengisahan kisah cinta Bagus dan Chaya penulis memberikan gambaran mengenai berbagai realitas kehidupan masyarakat di kota Serdang pada masa lalu. Berdasarkan studi yang dilakukan dapat dipahami bahwa berbagai gambaran yang ada di dalam novel ini memperlihatkan kesejajaran struktur dengan realitas pada dokumen-dokumen sejarah yang ada. Di sisi lain, novel ini juga memberikan kritik terhadap sikap pemerintah saat ini yang abai terhadap sejarah masa lalu yang kaya, utamanya di wilayah Serdang.

\section{Ucapan Terima Kasih}

Penulis menyampaikan ucapan terima kasih kepada Rektor Universitas Muhammadiyah Malang dan Kaprodi Pendidikan Bahasa Indonesia atas dukungannya terhadap penelitian ini. Selain itu, penulis juga mengucapkan terima kasih kepada reviewer anonim yang telah memberikan masukan terhadap artikel ini sehingga menjadi lebih baik.

\section{Daftar Pustaka}

Abdullah, I. (2017). Glokalisasi Identitas Melayu: Potensi dan Tantang Budaya Dalam Reproduksi Kemelayuan. MANHAJ: Jurnal Penelitian dan Pengabdian, 6(2), 1-7. Retrieved from

https://ejournal.iainbengkulu.ac.id/in dex.php/manhaj/article/view/742/65 $\underline{9}$

Andalas, E. F. (2016a). Citra Antikolonial dalam Film Avatar (2009): Sebuah Tinjauan Poskolonial. Puitika, 12(1), 1-10. Retrieved from http://jurnalpuitika.fib.unand.ac.id/in dex.php/jurnalpuitika/article/view/26

Andalas, E. F. (2016b). Sastra Lisan Lakon Lahire Panji Pada Pertunjukan Wayang Topeng Malang Padepokan Mangun Dharma (Kajian Sastra Lisan Ruth $H$ Finnegan). (Master Master Thesis), Universitas Airlangga, Surabaya.

Andalas, E. F. (2017a). Dampak dan Fungsi Sosial Mitos Mbah Bajing bagi Kehidupan Spiritual Masyarakat Dusun Kecopokan Kabupaten Malang Jawa Timur. Puitika, 13(1), 21-31. Retrieved from http://jurnalpuitika.fib.unand.ac.id/in dex.php/jurnalpuitika/article/view/48

Andalas, E. F. (2017b). Eskapisme Realitas dalam Dualisme Dunia Alice Telaah Psikologi-Sastra Film Alice in Wonderland (2010). KEMBARA: Jurnal Keilmuan Bahasa, Sastra, dan Pengajarannya, 3(2), 185-195. doi:https://doi.org/10.22219/KEMB ARA.Vol3.No2.185\%20-\%20195

Andalas, E. F. (2018a). Literasi Ekologis: Tanggung Jawab Moral Ilmu Sastra dalam Pengelolaan Ekologi Manusia. Paper presented at the Seminar Nasional Bahasa dan Sastra Indonesia (SENASBASA), Malang. 
Andalas, E. F. (2018b). Meninjau Kembali Identitas Budaya Jawa Di Era Globalisasi: Panji Sebuah Representasi Identitas Lokal Jawa Timur. Paper presented at the Seminar Kebudayaan Jawa (Budaya Jawa dalam Tantangan Globalisasi dan Pengembangan Budaya Nasional), Malang. http://www.academia.edu/download/ 61763945/10._MeninjauKembaliIde ntitasBudayaJawadiEraGlobalisasi-

PanjiSebuahRepresentasiIdentitasLo kalJawaTimur420200112-76572q6nor.pdf

Andalas, E. F. (2018c). Reimajinasi Kebenaran Kajian Sastra dan Budaya dalam Perspektif Cultural Studies. In E. F. Andalas \& H. B. Qur'ani (Eds.), Narasi Katulistiwa: Sehimpun Telaah Kritis Atas Kepingan-Kepingan Kisah Manusia dalam Drama Indonesia. Malang: Kota Tua.

Ardhianti, M. (2016). Kajian New Historicism Novel Hatta: Aku Datang Karena Sejarah Karya Sergius Sutanto Buana Sastra, 3(1), 1-10. Retrieved from http://jurnal.unipasby.ac.id/index.ph $\mathrm{p} / \mathrm{bastra} /$ article/view/652/519

Ariani, M. F., \& Andalas, E. F. (2018). Kearifan Lokal Malangan dalam Kumpulan Cerpen Aloer-Aloer Merah Karya Ardi Wina Saputra. JURNAL SATWIKA, 2(2), 107-118. doi:https://doi.org/10.22219/SATWI KA.Vol2.No2.107-118

Azhari, I. (2013). Kesultanan Serdang: Perkembangan Islam pada Masa Pemerintahan Sulaiman Shariful Alamsyah Jakarta: Badan Litbang dan Diklat Kementerian Agama Republik Indonesia.

Barry, P. (2010). Pengantar Komprehensif Teori Sastra dan Budaya: Beginning Theory. Yogyakarta: Jalasutra.
Brannigan, J. (1999). Introduction: History, Power, and Politics In the Literary Artifact. New York: New York University Press.

Budianta, M. (2006). Budaya, Sejarah, dan Pasar: New Historicism dalam Perkembangan Kritik Sastra. Jakarta: Yayasan Obor Indonesia.

Farida, N., \& Andalas, E. F. (2019a). Eksistensi Kearifan Lokal Madura di Era Modern dalam Celurit Hujan Panas Karya Zainul Muttaqin. Atavisme, 22(2), 217-232. doi:https://doi.org/10.24257/atavism e.v22i2.581.217-232

Farida, N., \& Andalas, E. F. (2019b). Representasi Kesenjangan SosialEkonomi Masyarakat Pesisir Dengan Perkotaan Dalam Novel Gadis Pantai Karya Pramodya Ananta Toer. KEMBARA: Jurnal Keilmuan Bahasa, Sastra, dan Pengajarannya, 5(1), 74-90. doi:https://doi.org/10.22219/KEMB ARA.Vol5.No1.74-90

Foucault, M. (2012). Arkeologi Pengetahuan. Jakarta: IRCiSoD.

Greenblatt, S. (1982). The Power of Forms in The English Renaissance (S. Greenblatt Ed.). Okla: Pilgrim Books.

Greenblatt, S., \& Gallagher, C. (2005). Practicing New Historicsm. Chicago: The University of Chicago Press.

Hashim, M. Y. (1988). Di Antara Fakta dan Mitos: Tradisi Pensejarahan Di Dalam Hikayat Siak Atau Sejarah Raja-Raja Melayu SEJARAH: Journal of the Department of History, 1(1), 63-116. doi:https://doi.org/10.22452/sejarah. vol1no1.3

Iman, N., \& Andalas, E. F. (2019). Representasi Kehidupan Religius Masyarakat Islam Kejawen Di 
Yogyakarta Pada Tahun 1868 M1912 M dalam Novel Dahlan: Sebuah Novel Karya Haidar Musyafa. Pena Literasi, 2(1), 189-200. Retrieved from

https://jurnal.umj.ac.id/index.php/pe naliterasi/article/view/4448

Iskandar, P. (2010). Economics: Pengantar Mikro dan Makro. Jakarta: Mitra Wacana Media.

Kartodirjo, S. (1992). Pendekatan Ilmu Sosial dalam Metodologi Sejarah Jakarta: Gramedia Pustaka Utama.

Massardi, Y. A. N. M. (2019). Penari Dari Serdang Jakarta Gramedia Pustaka Utama

Mohammad, G. S. (2017). Jawasentris dalam Penulisan Sejarah Nasional Indonesia. Paper presented at the 60 Tahun Seminar Sejarah Nasional Indonesia, Yogyakarta. http://www.academia.edu/download/ 59765721/Ghamal_Satya_Mohamm ad_Universitas_Indonesia_Jawasentr is_dalam_Penulisan_Sejarah_Nasion al_Indonesia20190617-72068x8893x.pdf

Mumtaz, F. (2014). Membongkar Kubur Sugiarti Siswadi (Sebuah Kajian New Historicism) (Master Master Thesis), Universitas Sanata Dharma, Yogyakarta. Retrieved from https://repository.usd.ac.id/124/2/09 6322014 full.pdf

Purnamasari, B. W. A. (2019). Novel Arok Dedes Karya Pramoedya Ananta Toer Dengan Kajian New Historicism Stephan Greenblatt. BAPALA, 5(2), 1-10. Retrieved from https://jurnalmahasiswa.unesa.ac.id/i ndex.php/bapala/article/view/28172/ 25774

Putra, B. A. (2016). Historiografi Melayu: Islam Dalam Sejarah dan Kebudayaan Melayu. Tsaqofah dan
Tarikh: Jurnal Kebudayaan dan Sejarah, 1(1), 91-102. Retrieved from

https://ejournal.iainbengkulu.ac.id/in dex.php/twt/article/view/866/739

Qur'ani, H. B., \& Andalas, E. F. (2019). Nilai-Nilai Moral Cerita Rakyat di Banten. Basastra: Jurnal Kajian Bahasa dan Sastra Indonesia, 8(3), 238-252.

doi:http://dx.doi.org/10.24114/bss.v8 i3.15885

Ranjabar, J. (2006). Sistem Sosial Budaya Indonesia. Bogor: Ghalia Indonesia.

Sahliyah, C. (2017). Kajian New Historicism Novel Kubah Karya Ahmad Tohari. Jurnal Pendidikan Bahasa dan Sastra, 17(1), 108-116. doi:https://doi.org/10.17509/bs_jpbs p.v17i1.6962

Salleh, S. H. (1997). Kesusasteraan melayu Abad Kesembilan Belas. Kuala Lumpur: Dewan Bahasa dan Pustaka.

Sinar, T. L. (1986). Sari Sejarah Serdang 2. Jakarta: Departemen Pendidikan dan Kebudayaan.

Sugiarti, S., \& Andalas, E. F. (2018). Perspektif Etik dalam Penelitian Sastra. Malang: UMM Press.

Sugiarti, S., Andalas, E. F., \& Setiawan, A. (2020). Desain Penelitian Kualitatif Sastra. Malang: UMM Press.

Sulistyorini, D., \& Andalas, E. F. (2017). Sastra Lisan: Kajian Teori dan Penerapannya dalam Penelitian. Malang: Madani.

Taum, Y. Y. (2013). Representasi Tragedi 1965: Kajian New Historicism Atas Teks-Teks Sastra dan Nonsastra tahun 1966-1998 (Ringkasan Disertasi). Universitas Gadjah Mada Yogyakarta. Retrieved from https://www.academia.edu/3540108/ REPRESENTASI_TRAGEDI_1965 


\section{_KAJIAN_NEW_HISTORICISM \\ ATAS_TEKS- \\ TEKS_SASTRA_DAN_NONSAST \\ RA_TAHUN_1966_- \\ _1998_Ringkasan_Disertasi_}

Teeuw, A. (1974, Juni). Sastra dalam Ketegangan Antara Tradisi dan Pembaharuan. Basis, XXVII.

Wellek, R., \& Waren, A. (2014). Teori Kesusastraan. Jakarta: Grasindo.

Zakaria, N. b., Ali, A. H. b., Wahid, A. b., \& Omar, A. b. (2018). Sejarah Melayu Sebagai Lambang Tradisi Akal Budi Bangsa yang Tinggi. JURNAL MELAYU SEDUNIA, 1(1), 191-209. Retrieved from https://ejournal.um.edu.my/index.ph p/jurnalmelayusedunia/article/view/1 $\underline{3389 / 8519}$ 